\title{
THEORETICAL-LEGAL CHARACTERISTICS OF LEGAL CONFLICT IN LEGAL RELATIONS ON ADMINISTRATIVE SUPERVISION
}

\section{Denysova A. V.}

\section{INTRODUCTION}

The need to formalize the implementation determinant of certain types of administrative supervision, in particular in the areas of public security and order, combating corruption and taking into account the implementation peculiarities of certain procedures of administrative supervision of the executive authorities, makes relevant the use of scientific potential of legal conflictology, which is of particular importance in administrative supervision's context. The expediency of addressing the legal conflict in the relations with regard to administrative supervision by the state executive power organs from the appointment of supervision, which consists in establishing the degree compliance by a entity whose activity is a supervision item prescribed by the legislation. The legal conflict's essence follows from its features, which are recorded in the current legislation in the form of special legal states, conflict situations, prohibitions, as well as violations of established legal requirements. This means that the existence of legal requirements and the obligation to comply with them is a conflicting factor affecting the legal relationship, as well as the administrative supervision of the state executive bodies.

Selection of groups of administrative proceedings, which are based on the existence (absence) of a conflict of legal importance. Conflicts and nonconflicts proceedings are distinguished, and the latter's subject are those in the course of which it is not obligatory to carry out a legal assessment of a person's behavior in relevant legal relationships. Conflict proceedings are those that underpin administrative-legal conflict, and therefore the legal assessment of a person's conduct in legal relationships.

It is advisable to classify administrative supervision proceedings as conflicting, since their implementation involves the provision of a legal assessment as a result of inspections or other measures (e.g. monitoring).

\section{Signs of administrative-legal conflict}

In the area of administrative supervision by the executive authorities, it is advisable to distinguish among the signs of administrative and legal conflict those which are caused by the peculiarities of the said activity:

- it always has a public-legal nature, since it arises from a public-legal relationship; 
- arises from legal relations connected with the implementation by the authorized bodies of the state executive power of executive activity aimed at establishing the compliance's degree of the entity's activity;

- whose activity are subject to administrative oversight;

- the current legislation, as well as guaranteeing safety in certain spheres of life of population.

The content and nature of the administrative-legal conflict in the legal relations concerning the implementation of administrative supervision consists in the existence of conflicting interests in the subjects of relations in the implementation of administrative supervision, one of which is always a state-authorized entity with a special legal status and performing state-power functions, and another entity whose activities are subject to administrative oversight does not perform such functions.

The last sign of administrative-legal conflict in the activities of state executive bodies in the exercise of administrative supervision follows from the following signs of legal conflict: a) the presence of contradictions or conflicts in the parties to the conflict; b) the existence of conflicting interests in the sphere of activity of the executive authorities on one subject; c) presence of the conflict subject with legal status; d) the decision within the limits of a certain legal procedure determined by administrative and legal norms; e) the existence of legal consequences of a decision, which is manifested, in particular, in the procedures for bringing to one of the types of legal responsibility (administrative, disciplinary, criminal), or imposing financial sanctions in the form of fines, or in denial of permits, or in restoration of the infringed right, etc ${ }^{1}$.

Appeal to legal encyclopedic publications indicates the insight of the category's essence of "public-legal dispute" as a type of legal dispute that arises between participants of public-legal relations in connection with violation, application or interpretation of rules of public branches of law. Contradictions that characterize the content of a public-law dispute are expressed in the differences in the legal positions of participants in a publiclaw relationship regarding their rights and obligations or the legality of a lawful (administrative) or normative act $^{2}$.

In "Great Encyclopedic Legal Dictionary" the category's content of "public-legal dispute" coincides with the category "public-legal conflict",

${ }^{1}$ Гасанова А. К. Адміністративно-правові засади вирішення конфліктів в діяльності органів виконавчої влади: дис..к.ю.н. 12.00 .07 - адміністративне право і процес; фінансове право; інформаційне право / Гасанова Антоніна Керимівна / Національний університет "Одеська юридична академія”. Одеса, 2011. 215 с.

${ }^{2}$ Великий енциклопедичний юридичний словник / За ред.. акад.. НАН України Ю. С. Шемшученка. 2-ге вид., переробл.і доповн. К.: Вид-во “Юридична думка", 2012. $1020 \mathrm{c}$. 
since the sole legal phenomenon - the contradiction between these relations' participants, is based on their content's insight.

Considering that the category of "public-legal dispute" is used in the current legislation - the Code of Administrative Procedure of Ukraine - it is possible to propose to provide a broad and narrow understanding of the public-legal dispute. The broad understanding presented above by Yu.S. Pedko is the author of the corresponding definition in the Great Encyclopedic Legal Dictionary. In the broad sense, the categories "publiclegal dispute" and "public-legal conflict" are identical in meaning. A narrow understanding of the category of "public-law dispute" is limited to its definition as a subject of judicial administrative jurisdiction.

In administrative out-of-court jurisdiction, administrative-legal conflict is regarded as an administrative-legal phenomenon, derived from a public-legal conflict. This means that the category of "public-legal conflict" is generic, and "administrative-legal conflict" is a generic one. It should be borne in mind that the content of the administrative-legal conflict is revealed through its elements: parties (subjects), subject matter and grounds for occurrence. Such elements constitute the construction of a public-law dispute ${ }^{3}$ and can be used to characterize administrative-legal conflicts in the activities of executive authorities as the basis for the emergence of procedural administrative-judicial extrajudicial relations. At the same time, this approach is not unique in identifying elements of legal conflict (dispute). A.K. Hasanov proposes that elements of legal conflict in the activity of executive bodies include: a) parties (entities); b) the subject; c) the content.

Comparison of the above approaches to the selection of legal conflict's elements, public-legal dispute indicates that they differ in the content of the conflict and grounds for the dispute. In this context, it should be noted that the need to identify the grounds for a dispute or conflict arises when the task of preventive measures is implemented in order to prevent or resolve a conflict or controversial situation. Identifying the cause of the dispute allows us to find out the outside of this legal phenomenon. Internal features of the administrative-legal conflict in the activity of executive authorities can be characterized using the approach proposed by A.K. Hasanov, on the composition of elements of administrative-legal conflict.

Thus, the elements of administrative and legal conflict in the activities of executive authorities include: a) parties (entities); b) the subject;

\footnotetext{
${ }^{3}$ Тимошенко К. О. Публічно-правовий спір як предмет юрисдикції адміністративних судів: автореф. дис.. к.ю.н. 12.00.07 - адміністративне право і процес; фінансове право; інформаційне право/ Тимошенко Катерина Олегівна / Інститут держави i права ім. В. М. Корецького НАН України. К., 2012. 20 с.
} 
c) the content. The need to include the subject matter and content as elements of administrative and legal conflict in the activities of executive bodies is based on the essence of these categories. So revealing the essence of these categories from the standpoint of philosophy allows us to note the following. Content reflects a system of interrelated components, properties, and processes that determine the specificity and development of an object. Subject ia any object that appears to be restricted or complete, why the properties may belong, and may have some relationship with other objects ${ }^{4}$. Thus the inner essence of a certain phenomenon, its properties, are characterized by content, and the boundaries of the phenomenon are delineated by the object.

However, the characterization of the administrative-legal conflict structure can be carried out in case of the types of such conflicts.

The signs of administrative and legal conflict include:

- the presence of conflicting or incompatible interests of participants in administrative and legal relations that arise within the specified legal relationship and relate to the same subject;

- participants in administrative-legal conflict have the appropriate administrative-legal status;

- such a conflict is resolved within the administrative procedure established by law;

- there are legal consequences of resolving an administrative-legal conflict, related to the restrictions or relying on the subject, whose activity is subject to administrative supervision, the obligation to take certain actions provided by the current legislation.

- there are legal consequences of resolving an administrative-legal conflict, related to the restrictions or relying on the subject, whose activity is subject to administrative supervision, the obligation to take certain actions provided by the current legislation.

These signs of administrative-legal conflict are formulated on the basis of signs of legal conflict, taking into account the specifics of the emergence of administrative-legal conflict - the sphere of exercise by the public power entities (among them bodies of executive power) the powers of jurisdictional content.

Among the signs of administrative and legal conflicts, the first place indicates the signs of incompatibility or conflict of interest. Revealing the essence of the category of "interest", it is expedient to proceed from its constitutional and legal content, reproduced in the legal position of the Constitutional Court of Ukraine "In the case of the constitutional submission

${ }^{4}$ Философия: энциклопедический словарь / под ред. А. А. Ивина. М.: Гардарики, 2006. $1072 \mathrm{c}$. 
of the 50 People's Deputies of Ukraine on the official interpretation of certain provisions of part one of Article 4 of the Civil Procedure Code of Ukraine (case of interest protected by law)" No. 18-2004 of 01.12.2004, namely its resolution part. Thus, in paragraph 1 of the resolution part of the decision, it stated that the concept of "law-protected interest" used in part one of Art. 4 of the Civil Procedure Code of Ukraine and other laws of Ukraine in a logical and meaningful connection with the concept of "a right", should be understood as the desire to use a specific material and / or intangible welfare, as determined by the general content of the objective and not directly mediated in the subjective law is a simple legitimate solution that is an independent object of judicial protection and other legal remedies in order to meet individual and collective needs that are not contrary to the Constitution and laws of Ukraine, the public interest, justice, integrity, reasonableness and other general legal principles 5 .

Therefore, the category of "interest" in its legal meaning means legitimate interest, which is manifested in the legislative regulation of the respective rights and freedoms.

Administrative-legal conflicts that give rise to administrative oversight relationships can be called administrative-legal conflicts in rule of law. Such a proposal is based on the essence of the category of "rule of law", which is revealed through public relations based on law. Rule of law is the ordering of legal, political, economic social and other relations by means of laws and other legal acts. It is, in fact, the result of the implementation of rules of law, accurate and steady implementation of laws and other normative legal acts, i.e. legality. The contradictions that arise in this area do not necessarily lead to the emergence of administrative-tort relations in connection with the commission of administrative tort or violation of rights, freedoms, legitimate interests, but act as conditions of occurrence.

Thus, an administrative-legal conflict in the sphere of administrative oversight of the executive authorities is a legal phenomenon, which is public and legal in nature, and concerns the existence of entities, one of which is endowed with a special legal status and performs state-governmental functions with opposite interests in legal relations, related to the implementation of enforcement activities aimed at establishing the degree and degree of compliance of the entity subject to administrative supervision, current legislation, as well as guaranteeing safety specific areas of the population.

5 У справі за конституційним поданням 50 народних депутатів України щодо офіційного тлумачення окремих положень частини першої статті 4 Цивільного процесуального кодексу України (справа про охоронюваний законом інтерес): рішення Конституційного Суду України від 01.12.2004 p. № 18-рп/2004// Офіційний вісник України. 2004. № 50. Ст. 3288. 
Such administrative-legal conflicts are administrative-legal conflicts in the field of law and order. They can be summarized in two groups: 1) tort conflicts, which in turn are divided into administrative-tort and disciplinary; 2) conflicts that result in a person exercising the right of appeal in an administrative manner.

However, the systematization of administrative and legal conflicts in the field of rules of law, which are considered from the standpoint of determining the use of certain types of administrative oversight of the executive authorities, involves taking into account the subject of a certain type of administrative supervision.

Thus, the Law of Ukraine "On State Market Supervision and Control of Non-Food Products" of 02.12.2010 No. 2735-VI ${ }^{6}$ stipulates that state market surveillance (hereinafter-market surveillance) is the activity of market surveillance authorities in order to ensure the conformity of products with the established requirements, as well as ensuring that there are no threats to the public interest (Article 1). Specific requirements for the exercise of market surveillance for specific types of products may be laid down in technical regulations (Part 2 of Article 2). The purpose of market surveillance is to take restrictive (corrective) measures with appropriate publicity for products that, when used for their intended purpose or reasonably foreseeable conditions and with proper installation and maintenance, pose a threat to the public interest or which otherwise does not meet the public interest requirements (Part 1, Art. 4).

Therefore, based on the above-mentioned regulatory requirements for the implementation of state market surveillance, its determinant is a conflict related to the violation of technical regulations, established product requirements or the presence of threats to the public interest. Conflict of state market surveillance determines its purpose for applying certain restrictive measures as a result of carrying out appropriate procedures. Such restrictive (corrective) measures are: a) restriction of production on the market; b) prohibition of making products on the market; c) withdrawal of products from circulation; d) recall of products (paragraph 2 of Part 1 of Article 22 of the Law of Ukraine "On State Market Supervision and Control of Non-Food Products" of 27.12.2010 No. 2735-VI). In the cases stipulated by the Law of Ukraine "On general safety of non-food products" No. $2736-\mathrm{VI}^{7}$ of 02.12 .2010 , the following market surveillance measures are

${ }^{6}$ Про державний ринковий нагляд і контроль нехарчової продукції: Закон України від 02.12.2010 № 2735-VI // Офіційний вісник України 2010, N 101 (10.01.2011), ст. 3602.

7 Про загальну безпечність нехарчової продукції: Закон України від 02.12.2010 № 2736-VI // Офіційний вісник України, 2010, N 101 (10.01.2011), ст. 3603. 
applied to the products that are in the consumers (users): 1) restricting the provision of products to the market; 2) recall of products (Part 3 of Article 22 of the Law of Ukraine "On State Market Supervision and Control of Non-Food Products" of December 27, 2010 No. 2735-VI). These measures are restrictive in nature, although they do not belong to administrative responsibility.

Given the existence of the right to apply restrictive measures in connection with violation of legal requirements and restrictions on the consequences of exercising a separate subspecies of administrative supervision of executive bodies - state market surveillance, it is advisable to supplement the list of tort conflicts, the subject of which is related to the existence of legal requirements.

Thus, the systematization of administrative-legal conflicts in the field of law and order as a determinant of the exercise of administrative supervision by the state executive authorities provides for the allocation of:

1) tort conflicts, which are divided into: a) administrative and tort; b) conflicts, the subject of which is related to the presence of legal requirements and restrictions; c) disciplinary conflicts;

2) managerial conflicts, the existence of which is the basis of administrative appeal.

Administrative-legal conflicts include a group of tort conflicts, which may result in administrative misconduct or disciplinary misconduct, as well as conflicts that are subject to legal requirements and restrictions.

According to Part 1 of Article 9 of the Code of Ukraine on Administrative Offenses (hereinafter referred to as the Code of Administrative Offenses) ${ }^{8}$, an administrative offense (misdemeanor) is recognized as unlawful, guilty (intentional or negligent) act or omission that infringes on public order, property, rights and freedom of citizens, in accordance with the established procedure of administration and for which the law provides for administrative responsibility.

Based on the prescriptions of Part 1 of Article 9 of the Code of Administrative Offenses, the parties to the administrative-delict conflict may act as a person who has violated mandatory rules and who should bear administrative responsibility for such violation, on the one hand, and the state as the authorized bodies charged with the duty to provide, preserve public order, public safety, established management order. The object of the emergence of conflicting interests in an administrative-tort conflict, which results in an administrative act, are relations in the public order sphere,

\footnotetext{
${ }^{8}$ Кодекс України про адміністративні правопорушення від 07.12.1984 № 8073-Х // Відомості Верховної Ради УРСР, 1984, додаток до N 51, ст. 1122.
} 
property, rights and freedoms of citizens, established management order. The opposite of interests is thus manifested by the unlawfulness of the act of the subject of administrative misconduct and the duty of the authorized state bodies to exercise legal protection and protection against unlawful encroachments.

In this case, the conflict of interests is characterized by the position of social and legal, because a person, in violation of mandatory rules of conduct protected by the state, thereby encroaches on the rule of law. Conflict of administrative-tort relations is also manifested in their development, transformation into relations of administrative responsibility, when a person against whom a protocol on an administrative offense has been drawn up, is obliged to obey the established rules, regardless of the fact that there is an imperative interference with his private interests.

In this connection it is impossible to avoid the opinion of L.V. Koval which was referred to by D.M. Lukyanets, that the administrative-tortious attitude arises from the moment of committing an administrative misdemeanor, and responsibility in the narrow sense as the application of punishment, takes place only from the moment of recognition of the person guilty, his/her conviction ${ }^{9}$.

Characteristic of administrative misconduct from the standpoint of legal conflictology is appropriate, because this approach allows to identify the risks of possible violations of the existing order of bringing to administrative responsibility by identifying "conflict" factors in the implementation of authorized state bodies (their officials in administration of imperative administration) imperative powers within the framework of administrativejurisdictional proceedings in cases of administrative misconduct. However, should be taken into account, that the category of "conflict" in law is of social-importance, which indicates the need to take into account the moment of transition of the conflict state into a conflict relationship, which occurs when the administrative misconduct is discovered and the last signs of a legal fact are acquired.

It is possible to mention in this context the scientific controversy of P.P. Serkov with scientists who disputed on legal relations arising in cases of administrative offenses. Scientists, criticizing O.B. Zelentsov, E.B. Luparev, who stated that the current legislation directly provides for the possibility of a legal dispute on administrative and tax liability, noted the following. The "dispute" category is more inherent in situations related to general regulatory

\footnotetext{
9 Лук'янець Д.М. Адміністративно-деліктні відносини в Україні: теорія та практика правового регулювання: Монографія, - Суми: ВТД “Університетська книга", 2006. $367 \mathrm{c}$.
} 
norms, as well as administrative law, for example, on justification of satisfaction or refusal to satisfy any rights or responsibilities, but not in the case of administrative liability ${ }^{10}$.

The autjor should agree with the argument of P.P. Serkov and acknowledge that administrative-tort relations cannot be described as disputed. However, their conflict is obvious, but it should be noted that it is advisable to consider administrative-tort conflict as a condition for the emergence of tort relations.

A similar theoretical-legal analysis can be made regarding disciplinary misconduct, taking into account the peculiarities of disciplinary responsibility. O.V. Kuzmenko defines the following specific features of disciplinary responsibility: 1) the basis for the application of disciplinary measures is the commission of a disciplinary misconduct, i.e. violation of the rules or governing rules, the activities of collectives, enterprises, institutions, organizations, etc.; 2) as a rule, for disciplinary misconduct, a person is liable in the order of labor or official jurisdiction; 3) disciplinary responsibility provides for the application to the offender of a wide range of specific sanctions: verbal remarks; deprivation of another rank from the location of a military unit or ship ashore appointment out of turn to work attire; severe reprimand; disciplinary fine; placement in a cell or solitary confinement; arrest with custody at the guard house; withdrawal of incentives previously applied; warnings about incomplete job title; delaying the assignment of another special rank; demotion in a special rank (class rank); demotion; a one-step reduction in military rank with a transfer to a lower position; dismissal, etc ${ }^{11}$.

Taking into account the above specific features of disciplinary responsibility, it can be stated that the parties to the disciplinary conflict are the subjects of employment and labor relations, which are connected with each other by organizational subordination. The subject-matter of such a conflict concerns the employment-related interests of a career in the broad sense of the term with respect to public service employees. If you rely on the legislative definition of the term "public service", you should refer to the norm of paragraph 15 of Part 1 of Art. 3 of the Code of Administrative Judiciary of Ukraine, which states that public service - activity in state political positions, professional activity of judges, prosecutors, military service, alternative (non-military) service, diplomatic service, other civil

\footnotetext{
${ }^{10}$ Серков П.П. Административная ответственность в российском праве: современное осмысление и нове подходы: монография / П.П. Серков. М.: Норма: ИНФРА-М, 2012. $480 \mathrm{c}$.

${ }^{11}$ Кузьменко О.В. Адміністративно-процесуальне право України / [О.В. Кузьменко, Т.О. Гуржій] : підруч.; за ред. О.В. Кузьменко. К.: Атіка, 2007. 416 с.
} 
service, service in the authorities of the Autonomous Republic of Crimea, bodies Local Government. The content of a disciplinary tort conflict is in the conflict of interests of the subjects of labor relations.

Torts are the ones that are subject to legal requirements and restrictions. This subgroup of tort conflicts makes up the vast majority of conflicts as determinants of administrative oversight by state executive bodies. Particular conflicts are those conflicts, the subject of which is related to the presence of legal requirements and restrictions established in the field of public order and security, certain areas of ensuring the safety of life of the population.

\section{The essence of conflict as a determinant of implementation of control and supervisory activities by executive authorities}

Tort conflicts from the standpoint of determination of the exercise of control-supervisory activity by the state executive power bodies, it is necessary to emphasize that there are such restrictions, the consequence of violation of which is not bringing to administrative or other types of legal responsibility, but acceptance by the authorized bodies of state executive power (their officials) decisions in the form of legal acts that provide for specific legal consequences of burdensome nature against violators of established legal requirements and restrictions.

For example, state nuclear and radiation safety inspectors carrying out administrative oversight in accordance with the Procedure for State Supervision of Compliance with Nuclear and Radiation Safety Requirements, approved by the Cabinet of Ministers of Ukraine Decree No. 824 of November $13,2013^{12}$, are authorized to issue orders as written requirements addressed to legal entities, their officials and individuals in case of violation of the requirements of nuclear and radiation safety.

Thus, a written request issued to legal entities, their officials and entities - entrepreneurs in order to stop the identified breach of the requirements of nuclear and radiation safety, eliminate its consequences or take compensatory measures to mitigate such consequences. The decree is issued by state inspectors of nuclear and radiation safety, has a binding nature, and its requirements must be fulfilled within a specified term (p. 5 p. 2 of the "Procedure for carrying out state supervision of compliance with the requirements of nuclear and radiation safety", approved by the Cabinet of Ministers resolution Ukraine, dated November 13, 2013 No. 824).

${ }^{12}$ Про затвердження Порядку здійснення державного нагляду за дотриманням вимог ядерної та радіаційної безпеки: Постанова Кабінету Міністрів України від 13.11.2013 № 824 // Офіційний вісник України, 2013, N 91 (03.12.2013), ст. 3344. 
A written request issued to legal entities, their officials and natural persons - entrepreneurs with the purpose of limiting, stopping the operation of state surveillance facilities in case of failure to eliminate otherwise detected violations or failure to comply with the requirements of nuclear and radiation safety. The decree is also issued by state inspectors for nuclear and radiation safety, is mandatory and its requirements must be fulfilled within the specified time limits (p. 6 p. 2 of the "Procedure of state supervision over compliance with the requirements of nuclear and radiation safety", approved by the Cabinet resolution Ministers of Ukraine, dated November 13, 2013 № 824).

Characterizing the peculiarities of administrative supervision of state executive bodies, their individual types, determinants, it is necessary to pay attention, first of all, to the problematic issues of legal regulation and law enforcement practice.

In particular, the results of the audit of the effectiveness of state budget funds' using by the National Commission for State Regulation in the Field of Communications and Informatization of the Accounting Chamber found the lack of legal regulation of the activities of the said National Commission, the lack of ensuring the proper enforcement of the powers of the licensing authority assigned to it by special laws of Ukraine. the licensing authority, the regulatory body and the state oversight (control) body in the communications sector. It is stated that the Decree on the National Commission for State Regulation in the Field of Communication and Informatization (hereinafter - the Regulations) ${ }^{13}$, approved by Presidential Decree No. 1067/2011, contains tasks and functions that are not mandated by law. Contrary to the requirements of Art. 8 of the Law of Ukraine "On postal service" of 04.10.2001 No. 2759-III The National Commission did not establish the procedure for state supervision of the postal services market, which led to the actual lack of implementation of powers to carry out supervision. Also in violation of the requirements of PP. 30 Clause 4 Regulations The National Commission did not approve the procedure for keeping a register of postal operators ${ }^{14}$.

${ }^{13}$ Про Національну комісію, що здійснює державне регулювання у сфері зв'язку та інформатизації: Указ Президента України від 23.11.2011 № 1067/2011 // Офіційний вісник України, 2011, N 94 (12.12.2011), ст. 3417

14 Про результати аудиту ефективності використання коштів державного бюджету Національною комісією, що здійснює державне регулювання у сфері зв'язку та інформатизації: Рішення Рахункової палати України від 09.03.2016 № 4-3 [Електронний ресурс]: Режим доступу. Інформаційно-аналітична система "Ліга-закон" станом на 12.07.2017. 
Referral to the current legislation does not provide an opportunity to point out the deficiencies indicated by the Accounting Chamber by the National Commission, in particular, the lack of a regulatory framework for the state supervision of the postal services market. There is currently information on the draft such a document, developed in 2010, in the form of an annex to the NCCIR decision No. 406 of 09/09/2010 ${ }^{15}$.

The next group of administrative-legal conflicts as determinants of the implementation of certain types of administrative supervision are conflicts, in which a person complains to state authorities, local self-government, associations of citizens, enterprises, institutions, organizations regardless of ownership, mass media, officials persons.

The conflicting nature of the complaint as a form of appeal, as well as to the executive authorities, stems from the legislative definition of the relevant designation. According to Part 4 of Art. 3 of the Law of Ukraine “On Citizens' Appeals" of 02.10.1996 № 393/96-VR ${ }^{16}$, complaint is a petition for renewal of rights and protection of the legitimate interests of citizens, violated by actions (inaction), decisions of state bodies, local authorities self-government, enterprises, institutions, organizations, associations of citizens, officials. Based on this regulatory definition of "complaint", it is necessary to point out the following elements of the relevant conflict. The parties of the conflict is the entity that has the authority to make legally significant decisions or take legally significant actions, on the one hand, and on the other - a citizen, a stateless person, a foreigner who have the right to appeal such a decision, an action (inaction). The right of foreigners, stateless persons to file a complaint derives from part 1 of Article 26 of the Constitution of Ukraine, which stipulates that foreigners and stateless persons who are legally in Ukraine exercise the same rights and freedoms and have the same duties, as well as citizens of Ukraine - with the exceptions established by the Constitution, laws or international treaties of Ukraine, as well as part 3 of Article 1 of the Law of Ukraine "On Citizens' Appeals", where it is established that persons who are not citizens of Ukraine and are legally within its territory, have and the same right to file an appeal as the citizens of Ukraine, unless otherwise provided by international treaties. The subject matter and content of the administrative-legal conflict relating to the complaint concerns the violation of socio-economic, political and personal rights and legitimate interests.

15 Порядок здійснення державного нагляду за ринком послуг поштового зв'язку: Додаток до рішення НКРЗ від 09.09.2010 р. № 406. [Електронний ресурс]: Режим доступу. nkrzi.gov.ua/images/upload/70/2429/r406dod.doc.

${ }^{16}$ Про звернення громадян: Закон України від 02.10.1996 р. № 393/96-ВР // Відомості Верховної Ради України. 1996. № 47. Ст. 256. 
Considering administrative-legal conflicts from the standpoint of determination of the implementation of certain types of administrative supervision by executive authorities, it should be noted that such conflicts should be considered as conditions for the emergence of procedural administrative-jurisdictional relations related to bringing a guilty person to administrative responsibility or disciplinary liability or protection of citizens' rights. Such relationships result from the implementation of certain types of administrative supervision. First of all, supervision in the fields of public safety and order, control and supervision in the internal organizational activity of executive bodies, certain types of administrative supervision in the sphere of ensuring the vital activity of the population (state sanitaryepidemiological supervision, supervision in the field of technogenic and fire safety, etc.).

The basis of administrative responsibility is an administrative misconduct. Administrative responsibility is realized on the condition of non-official subordination, there is a large number of bodies authorized to impose administrative penalties, the rules of administrative law determine the order of imposition of administrative penalties ${ }^{17}$.

Among the grounds of administrative responsibility it is advisable to distinguish factual and legal (procedural) grounds. The factual basis for proceeding in an administrative offense case is the fact of committing such an offense, and the legal one is the information about the offense. Scientists say that, in addition, there are reasons to be justified. Such reasons should be recognized: appeals (written or oral) to citizens; notification of officials of state authorities and local self-government, enterprises, institutions and organizations; media reports; messages from associations of citizens; direct detection of a misdemeanor by an authorized official ${ }^{18}$.

V.G. Perepelyuk systematized the grounds for initiating proceedings and identifies three groups. 1. Persons' statements demanding the exercise of their rights or the protection of those rights and the submission of leading entities. Citizens' statements may be oral. It is therefore envisaged that the oral statements should be entered in the minutes signed by the applicant and the official who accepted the application. 2. Own initiative of leading subjects. In case a petition is received from the applicant about the possibility of negative consequences associated with the filing of the application and in order to protect his/her interests, the case is initiated on

\footnotetext{
${ }^{17}$ Адміністративне право України. Академічний курс: Підруч.: У двох томах: Том 1. Загальна частина / Ред. колегія: В.Б. Авер'янов (голова) та ін. К.: ТОВ “Видавництво "Юридична думка", 2007. 592 с.

18 Адміністративна діяльність ОВС. Загальна частина. Підручник / За загальною редакцією О.П. Рябченко. Х.: ХНУВС, 2009. 256 с.
} 
the initiative of the leading entity. 3. Communication in the media ${ }^{19}$. We can agree with this approach, because it allows distinguishing the very reasons that require due process registration. The above applies, in particular, to citizens' statements.

Analyzing the issue of grounds of administrative responsibility, one should not fail to point out the legislative and doctrinal novelty - a category of criminal misconduct, the necessity of which was foreseen by the Concept of reforming criminal justice of Ukraine, approved by the Decree of the President of Ukraine of 15.02.2008 ${ }^{20}$. The following are proposed to be distinguished: 1) separate acts, which under the current Criminal Code of Ukraine belong to crimes of low gravity, which in accordance with the policy of humanization of criminal legislation will be determined by the legislator such that they do not have a significant degree of public danger; 2) envisaged by the current Code of Ukraine on Administrative Offenses that have judicial jurisdiction and are not administrative in nature (petty hooliganism, petty theft, etc.). The criminal offenses were to be divided into crimes and criminal offenses, as well as the unification of criminal proceedings under the new Criminal Procedure Code of Ukraine with civil and administrative justice, but as far as the peculiarities of the subject matter and the task of criminal justice.

The implementation of these strategic objectives is extremely difficult, given, first of all, the doctrinal uncertainty of this category itself. In the course of the scientific discussion, scientists express their opinion on the transformation of criminal rather than administrative legislation, linking it with the novelties of the Criminal Procedure Code of Ukraine, which provides for two types of criminal offense: crime and criminal offense ${ }^{21}$. Processing of this problem's results discussion among the leading domestic legal scholars has made the following conclusions. First of all, the adoption of the law on criminal offenses provides for the elimination of criminal law conflict, when the Criminal Procedure Code of Ukraine provides for the existence of criminal offenses, and the Criminal Code of Ukraine dated 23.04.2001 № 2341-III-no. The introduction of the institution of criminal misconduct into the legal system of Ukraine is connected with the reform of a number of law branches, including constitutional, criminal,

\footnotetext{
${ }^{19}$ Перепелюк В.Г. Адміністративний процес. Загальна частина: Навчальний посібник. Чернівці: Рута, 2003. 367 с.

${ }^{20}$ Про рішення Ради національної безпеки і оборони України від 15 лютого 2008 року "Про хід реформування системи кримінальної юстиції та правоохоронних органів": Президент України; Указ, Концепція від 08.04.2008 № 311/2008 // Урядовий кур’єр від 17.04.2008. № 72 .

21 Кримінальний процесуальний кодекс України від 13.04.2012 № 4651-VI// Офіційний вісник України, 2012, N 37 (25.05.2012), ст. 1370.
} 
administrative ones. The current Constitution of Ukraine lays down the concept of a single criminal offense - a crime. Therefore, it is practically impossible to implement the amendments to the Constitution of Ukraine, to introduce the institution of criminal misconduct in full and in the correct legal way. Possible "truncated version": to give the "status" of criminal misdemeanors to misdemeanor, while conducting systematic changes to the current Criminal Code of Ukraine. The introduction of the institution of criminal misconduct into the legal system of Ukraine should be carried out within the general concept of humanization of criminal responsibility and criminal justice as a whole. This raises the question of the harmonization with the concept of transfer to the category of criminal offenses of individual administrative offenses. Problematic, but rather interesting, is the proposal to introduce a new form of criminal liability for committing a criminal offense - criminal penalties. This form, in particular, can resolve the issue of criminal liability of legal persons, as provided for by numerous acts of international law, as well as the conventions of the Council of Europe and the European Union ${ }^{22}$.

Therefore, the introduction of a criminal misconduct institute is related to the solution of several interconnected conceptual problems. First of all, the above refers to the substantive part of the criminal and administrative legislation on the elaboration at the doctrinal level of the concept of criminal misconduct. Secondly, the question arises about the type of legal responsibility for committing a criminal offense - criminal, administrative or justify the feasibility of forming a new type of legal liability, which, in turn, provides for amendments to the Constitution of Ukraine. Thirdly, a considerable amount of analytical work is required to identify criminal offenses from criminal crimes and administrative offenses. Fourth, the procedure for bringing a criminal offense to justice should be proposed.

The solution to the whole range of these tasks is a difficult task, however, it is necessary, consider the humanization of legal responsibility, the tendency of which is in line with international standards.

Consideration may be given to the unification of the procedures for judicial review of individual cases, as well as those relating to criminal offenses, on a competitive basis. In this connection, it should be noted that in the writings of K.S. Yudelson, the idea of supplementing the competitive beginning of the civil process with the beginning of investigators was consistently held ${ }^{23}$.

\footnotetext{
${ }^{22}$ Курінний Є.В. Предмет і об’єкт адміністративного права України: Монографія. Д.: Юрид. акад. М-ва внутр. справ; Літера лтд, 2004. 340 с.

23 Юдельсон К. С. Избранное. Советский нотариат. Проблема доказывания в советском гражданском процессе. - М.: Росс. прав. академия, 2005. 616 с.
} 
With regard to disciplinary proceedings as a procedure for imposing disciplinary sanctions, the theory of administrative law has been based on disciplinary responsibility ${ }^{24}$. In the sphere of executive bodies' activity, the subject of disciplinary responsibility is primarily a civil servant. As correctly emphasized by L.M. Kornuta, the application of disciplinary liability is both a measure of disciplinary coercion and a type of legal liability applicable to civil servants. To the peculiarities of this type of responsibility, the researcher attributes the fact that issues related to bringing a civil servant to disciplinary responsibility are governed by the norms of both administrative and labor law ${ }^{25}$.

Disciplinary misconduct does not always serve as a basis for disciplinary responsibility. According to Article 15 of the Code of Administrative Offenses of Ukraine, military, military duty persons and reservists during the meeting, as well as persons of the rank and file of the State Criminal Enforcement Service of Ukraine, bodies of the National Police and the State Service for Special Communication and Information Protection of Ukraine are responsible for administrative offenses under disciplinary statutes. Exceptions are violations of rules, rules and standards relating to road safety, hygiene and sanitary-epidemic rules and regulations, rules of hunting, fishing and protection of fish stocks, customs rules, committing corruption offenses, disturbance of silence in public places. the use of state property, the unlawful storage of special technical means of obtaining information in private, the failure to take action on a separate court order or a separate judge's order, or the filing of a prosecutor, critically departed from fulfilling the legal requirements of the prosecutor, violation of the law on state secrets, breach of registration, storage and use of documents and other media containing confidential information held by the state for which these persons bear administrative responsibility on general grounds.

An exception to the general rule on disciplinary responsibility regarding the grounds of disciplinary liability - a disciplinary offense commission - is provided by the Law of Ukraine "On Prevention of Corruption" of 14.10.2014 No. 1700-VII ${ }^{26}$. According to Part 5, Article 65 of the said Law, a person who has been informed of a suspicion of crime committing in the

${ }^{24}$ Адміністративне право [Текст] : підручник / Ю. П. Битяк (кер.авт.кол.), В. М. Гаращук, В. В. Богуцький та ін. ; за заг.ред. Ю. П. Битяка, В. М. Гаращука, В. В. Зуй. Х. : Право, 2010. 624 с.

25 Корнута Л. М. Особливості дисциплінарної відповідальності державних службовців в Україні // Збірник наукових праць “Адміністративне право України: стан і перспективи розвитку”: VI Міжнародна науково-практична конференція (м. Київ, 23-24 вересня 2011 року)// Ред.кол. О. Ф. Андрійко (голова ред..кол.). К.: Інститут держави і права ім. В. М. Корецького НАН України, 2011. 600 с. С. 479.

${ }^{26}$ Про запобігання корупції: Закон України від 14.10.2014 № 1700-VII // Відомості Верховної Ради України, 2014, N 49 (05.12.2014), ст. 2056. 
field of official activity shall be subject to removal from the exercise of his / her powers in the manner prescribed by law. A person for whom a protocol on administrative corruption offense has been drawn up, unless otherwise provided by the Constitution and laws of Ukraine, may be suspended from the exercise of official authority by the decision of the head of the body (institution, enterprise, organization) in which he/she works, pending the case conclusion by a court. Part two of Art. 65 of the said law establishes that the person who has committed a corruption offense or an offense related to corruption, but the court did not punish or impose it in the form of deprivation of the right to occupy certain positions or engage in certain activities related to corruption, however, the court did not apply or impose a penalty on him/her in the form of deprivation of the right to occupy certain positions or engage in certain activities related to the performance of functions of the state or local self-government, or equivalent to these activities, subject to disciplinary liability in the manner prescribed by law.

It should be noted that separate rules on liability for corruption or corruptionrelated offenses under Art. 65 of the Law of Ukraine "On Prevention of Corruption" has been preserved, compared to Art. 22 of the Law of Ukraine "On the Principles of Prevention and Combating Corruption". The above applies to the provisions on peculiarities of administrative liability.

Therefore, the regulation peculiarities of disciplinary liability by the current legislation include:

- determination of norms of both administrative and labor law;

- for some categories of officials, the basis of disciplinary liability is the commission of an administrative offense, including corruption.

Regarding the complaint as a procedural basis for the emergence of procedural administrative-jurisdictional relations, it should be noted that its content consists in the requirement to restore the rights and legitimate interests of citizens violated by actions (inaction), decisions of state bodies, local self-government bodies, institutions, organizations, unions of citizens, enterprises, officials. Formulation this content follows from Part 3 of Art. 3 of the Law of Ukraine "On Citizens Appeal". In this regard, E.Yu. Shved correctly emphasizes the substantive nature of the complaint, as evidenced by an experience analysis of the Institute of Administrative Justice. This applies to countries such as the Netherlands, Austria, Poland, France. In the last two countries, along with the complaint, the appeal right was established in the form of a statement of claim ${ }^{27}$.

27 Швед Е. Ю. Процесуальні акти-документи у адміністративному судочинстві: дис. ... к.ю.н. 12.00.07 - адміністративне право і процес; фінансове право; інформаційне право / Швед Едуард Юрійович / Харківський національний університет внутрішніх справ. Х., 2009. 200 с. 


\section{CONCLUSIONS}

The essence of a legal conflict stems from its features, which are recorded in the current legislation in the form of special legal states, conflict situations, prohibitions, as well as violations of established legal requirements. This means that the existence of legal requirements and the obligation to comply with them is a conflict factor that affects the legal relationship, as well as the administrative oversight of state executive bodies.

Therefore, conflicts in legal relations regarding the administrative supervision of state executive bodies can be considered:

- as determinants of the application of certain types of administrative supervision;

- as grounds for the emergence of administrative and legal relations on the consequences of administrative supervision.

In the first and second cases, there are two sets of administrative-legal conflicts: tort and administrative conflicts. When considering a legal conflict from the standpoint of determination of certain administrative control and supervisory relations, a subset of conflicts, the subject of which is related to the presence of legal requirements and restrictions, is additionally included. At the same time, it should be emphasized that under different legal conditions (determination or consequence) there is a difference in the content of the structural components of legal conflicts. Administrative-legal conflicts are combined into one type of legal conflict - administrative-legal conflict in the field of law and order.

Systematization of administrative-legal conflicts in the field of law and order as a determinant of administrative supervision by state executive bodies provides for the allocation of: 1) tort conflicts, which are divided into: a) administrative-tort; b) conflicts, the subject of which is related to legal requirements and restrictions; c) disciplinary conflicts; 2) management conflicts, the existence of which is the basis of administrative appeal.

\section{SUMMARY}

The essence of a legal conflict stems from its features, which are recorded in the current legislation in the form of special legal states, conflict situations, prohibitions, including - in violation of established legal requirements. This means that the existence of legal requirements and the obligation to comply with them is a conflicting factor that affects the legal relationship, including the administrative supervision of state executive bodies.

The elaboration of scientific approaches to determine the essence of categories "legal conflict", "administrative-legal dispute", "public-legal dispute" allowed to include in the elements of administrative-legal conflict 
in the activity of bodies of executive power its subject and content. Formulate general features of such of the conflict, on the basis of which the signs of administrative-legal conflict in the sphere of administrative supervision are formulated. Torts are the ones that are subject to legal requirements and restrictions. This subgroup of tort conflicts makes up the vast majority of conflicts as determinants of administrative oversight by state executive bodies. Particular conflicts are those conflicts, the subject of which is related to the presence of legal requirements and restrictions established in the field of public order and security, certain areas of ensuring the safety of life of the population.

\section{REFERENCES}

1. Гасанова А.К. Адміністративно-правові засади вирішення конфліктів в діяльності органів виконавчої влади: дис. к.ю.н. 12.00 .07 адміністративне право і процес; фінансове право; інформаційне право/ Гасанова Антоніна Керимівна / Національний університет “Одеська юридична академія". - Одеса, 2011. - 215 с.

2. Великий енциклопедичний юридичний словник / За ред.. акад.. НАН України Ю.С. Шемшученка. - 2-ге вид., переробл. і доповн. - К.: Вид-во “Юридична думка", 2012. - 1020 с.

3. Тимошенко К.О. Публічно-правовий спір як предмет юрисдикції адміністративних судів: автореф. дис.. к.ю.н. 12.00.07 - адміністративне право і процес; фінансове право; інформаційне право / Тимошенко Катерина Олегівна/ Інститут держави і права ім.. В.М. Корецького НАН України. - К., 2012. - 20 с.

1) 4.Философия: энциклопедический словарь / под ред. А.А. Ивина. - М.: Гардарики, 2006. - 1072c.

4. У справі за конституційним поданням 50 народних депутатів України щодо офіційного тлумачення окремих положень частини першої статті 4 Цивільного процесуального кодексу України (справа про охоронюваний законом інтерес): рішення Конституційного Суду України від 01.12.2004 р. № 18-рп/2004 // Офіційний вісник України. 2004. - № 50. - Ст. 3288.

5. Про державний ринковий нагляд i контроль нехарчової продукції: Закон України від 02.12.2010 № 2735-VI// Офіційний вісник України, 2010, N 101 (10.01.2011), ст. 3602.

6. Про загальну безпечність нехарчової продукції: Закон України від 02.12.2010 № 2736-VI // Офіційний вісник України, 2010, № 101 (10.01.2011), ст. 3603. 
7. Кодекс України про адміністративні правопорушення від 07.12.1984 № 8073-Х // Відомості Верховної Ради УРСР, 1984, додаток до № 51, ст. 1122.

8. Лук'янець Д.М. Адміністративно-деліктні відносини в Україні: теорія та практика правового регулювання: Монографія, - Суми: ВТД “Університетська книга", 2006. - 367 с.

9. Серков П.П. Административная ответственность в российском праве: современное осмысление и нове подходы: монография/ П.П. Серков. - М.: Норма: ИНФРА-М, 2012. - 480 с.

10. Кузьменко О.В. Адміністративно-процесуальне право України / [О.В. Кузьменко, Т.О. Гуржій] : підруч.; за ред. О.В. Кузьменко. - К.: Атіка, 2007. - $416 \mathrm{c}$.

11. Про затвердження Порядку здійснення державного нагляду за дотриманням вимог ядерної та радіаційної безпеки: Постанова Кабінету Міністрів України від 13.11.2013 № 824// Офіційний вісник України, 2013, N 91 (03.12.2013), ст. 3344.

12. Про Національну комісію, що здійснює державне регулювання у сфері зв'язку та інформатизації: Указ Президента України від 23.11.2011 № 1067/2011 // Офіційний вісник України, 2011, № 94 (12.12.2011), ст. 3417.

13. Про результати аудиту ефективності використання коштів державного бюджету Національною комісією, що здійснює державне регулювання у сфері зв'язку та інформатизації: Рішення Рахункової палати України від 09.03.2016 № 4-3 [Електронний ресурс]: Режим доступу. - Інформаційно-аналітична система “Ліга-закон” станом на 12.07.2017.

14. Порядок здійснення державного нагляду за ринком послуг поштового зв'язку: Додаток до рішення НКРЗ від 09.09.2010 р. № 406 [Електронний ресурс]: Режим доступу. - www.nkrzi.gov.ua/images/upload/ 70/2429/r406dod.doc.

15. Про звернення громадян: Закон України від 02.10 .1996 p. № 393/96-ВР // Відомості Верховної Ради України. - 1996. - № 47. Ст. 256.

16. Адміністративне право України. Академічний курс: Підруч.: У двох томах: Том 1. Загальна частина / Ред. колегія: В.Б. Авер'янов (голова) та ін. - К.: ТОВ "Видавництво "Юридична думка", 2007. $592 \mathrm{c}$.

17. Адміністративна діяльність ОВС. Загальна частина. Підручник/ За загальною редакцією О.П. Рябченко. - Х.: ХНУВС, 2009. - 256 с.

18. Перепелюк В.Г. Адміністративний процес. Загальна частина: Навчальний посібник. - Чернівці: Рута, 2003. - 367 с. 
19. Про рішення Ради національної безпеки і оборони України від 15 лютого 2008 року "Про хід реформування системи кримінальної юстиції та правоохоронних органів": Президент України; Указ, Концепція від 08.04.2008 № 311/2008 // Урядовий кур'єр від 17.04.2008. - № 72 .

20. Кримінальний процесуальний кодекс України від 13.04.2012 № 4651-VI // Офіційний вісник України, 2012, N 37 (25.05.2012), ст. 1370.

21.Курінний Є.В. Предмет і об'єкт адміністративного права України: Монографія. - Д.: Юрид. акад. М-ва внутр. справ; Літера лтд,2004. - $340 \mathrm{c}$.

22. Юдельсон К.С. Избранное. Советский нотариат. Проблема доказывания в советском гражданском процессе. - М.: Росс. прав. академия, 2005. - $616 \mathrm{c}$.

23. Адміністративне право [Текст] : підручник / Ю.П. Битяк (кер.авт.кол.), В.М. Гаращук, В.В. Богуцький та ін. ; за заг.ред. Ю.П. Битяка, В.М. Гаращука, В.В. Зуй. - Х. : Право, 2010. - 624 с.

24. Корнута Л.М. Особливості дисциплінарної відповідальності державних службовців в Україні // Збірник наукових праць “Адміністративне право України: стан і перспективи розвитку”: VI Міжнародна науково-практична конференція (м. Київ, 23-24 вересня 2011 року) // Ред. кол. О.Ф. Андрійко (голова ред. кол.). - К.: Інститут держави і права ім. В.М. Корецького НАН України, 2011. - 600 с. C. 479.

25. Про запобігання корупції: Закон України від 14.10.2014 № 1700VII // Відомості Верховної Ради України, 2014, N 49 (05.12.2014), ст. 2056.

26. Швед Е.Ю. Процесуальні акти-документи у адміністративному судочинстві: дис..к.ю.н. 12.00.07 - адміністративне право і процес; фінансове право; інформаційне право / Швед Едуард Юрійович / Харківський національний університет внутрішніх справ. - X., 2009. - 200 c.

\section{Information about the author: Denysova A. V.,} Doctor of Law, Associate Professor, Head of the Department of Administrative Law and Administrative Process, Odessa State University of Internal Affairs 1, Uspenska str., Odessa, 65000, Ukraine 